\title{
Changes in Root Architecture After Amino Acid Application in a Soybean Crop
}

\author{
Walquíria F. Teixeira ${ }^{1}$, Evandro B. Fagan ${ }^{2}$, Luís H. Soares ${ }^{2}$, Ellen M. A. Cabral $^{1} \&$ Durval Dourado-Neto $^{1}$ \\ 1 “Luiz de Queiroz" College of Agriculture, University of Sao Paulo, Piracicaba, SP, Brazil \\ ${ }^{2}$ University Center of Patos de Minas, Patos de Minas, MG, Brazil \\ Correspondence: Walquíria F. Teixeira, Crop Science Department, "Luiz de Queiroz" College of Agriculture, \\ University of Sao Paulo, 13418-970, Piracicaba, SP, Brazil. Tel: 55-19-3429-4148. E-mail: \\ walquiria_bio@hotmail.com
}

Received: September 10, 2018

Accepted: October 23, 2018

Online Published: December 15, 2018

doi:10.5539/jas.v11n1p325

URL: https://doi.org/10.5539/jas.v11n1p325

The research is financed by the Coordenação de Aperfeiçoamento de Pessoal de Nivel Superior-Brasil (CAPES)-Finance Code 001.

\begin{abstract}
Improving the root system favors better plant growth, since it promotes water and nutrient absorption, resulting in higher plant yield. In this respect, the use of products for this purpose has become promising. Applying amino acids has benefitted the root system of Arabidopsis and in some vegetables; however, little is known about their influence on soybean plants. As such, the aim of this study was to assess the effect of applying amino acids to seeds and leaves on the root architecture of soybean plants. Effects of amino acids such as glutamate, cysteine, glycine and phenylalanine on the main root length (MRL), total root length (TRL), projected area (PA), root volume (RV), number of secondary roots (NSR), secondary root length (SRL) and number of tertiary roots (NTR) were evaluated. All the amino acids studied improved root architecture. Seed-applied cysteine increased TRL by $55 \%$, in relation to control. When applied on leaves, it raised TRL by $27 \%$ and MRL by $69 \%$, compared to control. Applying glycine to seeds increased MRL by $54 \%$, PA by $69 \%$, RV by $96 \%$ and NTR by $119 \%$, all in relation to control. Thus, amino acids enhanced the architecture of soybean roots. However, glutamate, glycine and phenylalanine produced better responses when applied to seeds, and cysteine, when applied to leaves. All of these changes may help roots absorb more water and nutrients, thereby raising crop yield.
\end{abstract}

Keywords: root development, glutamate, glycine, cysteine, phenylalanine

\section{Introduction}

Plant growth depends on water and the nutrients absorbed from the soil, substrate or nutrient solution. However, they are commonly grown in areas at risk of water deficit, due to unstable rainfall (FAO, 2011), and in environments with low levels of some nutrients, including nitrogen, phosphorous, zinc and boron (IPNI, 2016; Prochnow et al., 2018). Thus, the characteristics of the root system and its architecture are important in determining crop development.

Root system architecture is defined as the spatial arrangement of its individual parts (Shahzad and Amtmann, 2017). As such, it is determined from a set of traits, particularly morphology, topology and root distribution (Lynch, 1995), which establish how efficiently plants use the resources of the crop environment (Shahzad \& Amtmann, 2017).

In Brazil, Paula Neto (2013) demonstrated that the roots of coffee cultivars most efficient at absorbing phosphorous had a larger surface area, length, volume and tissue density. In China, Mi et al. (2010) observed that corn plants with deeper roots and vigorous lateral roots were more efficient at absorbing nitrogen in an intensive cropping system. Moreover, in a review, Li et al. (2016) found that a rise in efficient nutrient use by plants is related to better root system architecture.

Root system architecture shows high plasticity, due to the environmental, genetic and physiological characteristics of the plant. Thus, different strategies have been implemented in the field to shape root 
architecture. The use of amino acids to treat seeds or in foliar applications is one of the techniques employed to improve root development.

Glutamate is one of the amino acids that causes the largest number of changes in root system architecture. In this case, the effects are related to its role as signaler, via GLR receptors, as demonstrated by Forde's review (2014). Moreover, glycine and cysteine have also exerted an effect on root system architecture; however, the mechanisms that control these effects are even more obscure in relation to glutamate (Teixeira, 2016).

Although amino acids cause changes in root growth, a large number of studies have been conducted with products containing a mixture of amino acids, making it difficult to understand the effect that each one has when applied separately. Furthermore, to the best of our knowledge, this is the first study that assesses the effect of amino acids applied separately in seed treatments or to the leaves of a soybean crop.

As such, the aim of the present study was to evaluate the effect of applying glutamate, cysteine, glycine and phenylalanine in seed or leaf treatments on the modulation of soybean root architecture.

\section{Method}

The experiment was carried out in the greenhouse of the Department of Plant Production of the "Luiz de Queiroz" Superior Agricultural School (Esalq/USP), in Piracicaba, São Paulo state $\left(22^{\circ} 41^{\prime} \mathrm{S}, 47^{\circ} 38^{\prime} \mathrm{W}\right.$ and $546 \mathrm{~m}$ of altitude). The study was conducted in $11 \mathrm{dm}^{3}$ vases, containing washed sand as substrate, using the NS 7901 RR cultivar (Glycine max L. Merrill). Ten seeds per vase were planted and thinned after emergence, leaving only three plants per vase.

The experiment, performed using a random block design, consisted of applying amino acids to seeds or leaves, using eight blocks per treatment (Table 1). The dose used of each amino acid was determined from previous experiments that tested several doses of amino acids and were carried out by the research group itself. Before treatment application, all the seeds were treated with fungicide and insecticide [fipronil $\left(250 \mathrm{~g} \mathrm{~L}^{-1}\right)+$ methyl thiophanate $\left(225 \mathrm{~g} \mathrm{~L}^{-1}\right)+$ pyraclostrobin $\left.\left(25 \mathrm{~g} \mathrm{~L}^{-1}\right)\right]$ at a dose of $1 \mathrm{~mL} \mathrm{~kg}^{-1}$ of seeds.

Table 1. Concentration of different amino acids applied only on seed (ST) and foliar application (FA) at $\mathrm{V}_{4}$ stage

\begin{tabular}{lll}
\hline \multirow{2}{*}{ Amino acids ${ }^{1}$} & \multicolumn{1}{c}{ Moment of application } \\
\cline { 2 - 3 } & $\begin{array}{l}\text { Only seed treatment (ST) } \\
\left(\mathrm{mg} \mathrm{kg}^{-1} \text { [seeds] }\right)\end{array}$ & $\begin{array}{l}\text { Only foliar application (FA) at } \mathrm{V}_{4} \\
\left(\mathrm{mg} \mathrm{ha}^{-1}\right)\end{array}$ \\
\hline Control & 0 & 0 \\
Glutamate (Glu) & 12 & 123 \\
Cysteine (Cys) & 12 & 123 \\
Phenylalanine (Phe) & 3 & 30 \\
Glycine (Gly) & 9 & 92 \\
\hline
\end{tabular}

Note. ${ }^{1}$ The sources used correspond to the pure amino acids, with optical isomerism levogyrous (L-amino acid).

During the experiment, the vases were watered daily according to water needs ( $400 \mathrm{~mL}$ per vase). Nutrient solution was applied weekly, as proposed by Johnson et al. (1957).

\subsection{Assessments}

This analysis was carried out in stages $\mathrm{V}_{4}$ and $\mathrm{V}_{6}(25$ and 45 DAS), where two plants from each repetition were sampled for computational analysis of roots using Winrhizo ${ }^{\circledR} 4.1$ software, and an Epson XL 10000 scanner. Analysis followed the procedures proposed by Bouma et al. (2000). A resolution of 600 dpi was used to obtain the digital images. The roots were placed (not overlapped) on an acrylic cube containing $1 \mathrm{dm}^{3}$ of water.

Analysis was conducted based on the grey tones of each of the pixels that make up the image. The program automatically establishes a grey tone value, from which each plant tissue can be identified. These data were used to obtain main root length $\left(\mathrm{MRL}, \mathrm{cm}\right.$ plant $\left.\mathrm{t}^{-1}\right)$, total root length (TRL, $\mathrm{cm}$ plant $\left.\mathrm{t}^{-1}\right)$, projected area $\left(\mathrm{PA}, \mathrm{cm}^{2}\right.$ plant $\left.^{-1}\right)$, root volume (RV, $\mathrm{cm}^{3}$ plant $\left.{ }^{-1}\right)$, number of secondary roots (NSR), secondary root length (SRL, cm plant ${ }^{-1}$ ) and number of tertiary roots (NTR).

\subsection{Statistical Analysis}

The data obtained were assessed for normality and homogeneity using the Shapiro-Wilk and Levene tests, respectively, both at a 5\% significance level. Analysis of variance was carried out and, when significant, the 
Duncan's multiple-range test test was applied at a 5\% significance level. All the analyses were performed using SAS 9.3 software (SAS Institute, 2011).

\section{Results}

The use of glutamate, cysteine, phenylalanine and glycine promoted an increase in all the parameters related to root growth in stage $\mathrm{V}_{4}$ (Figures 1 and 2).

The plant seeds treated with glutamate, cysteine, phenylalanine and glycine exhibited greater main root length $(13,15,19$ and 17\%, respectively) compared to controls (Figure 1A). These treatments also raised root volume and number of tertiary roots to $100 \%$, when compared to controls (Figures 1D and 1G).

Cysteine application stood out most in terms of root growth parameters. This treatment increased root length by $55 \%$ in relation to controls (Figure 1B). The use of cysteine in seed treatment also raised the number and length of secondary roots by 52\% (Figures $1 \mathrm{E}$ and $1 \mathrm{~F}$ ). Increases of 29 and $39 \%$ were observed in the projected root area after cysteine and glutamate application, respectively, when compared to controls (Figure 1C). 

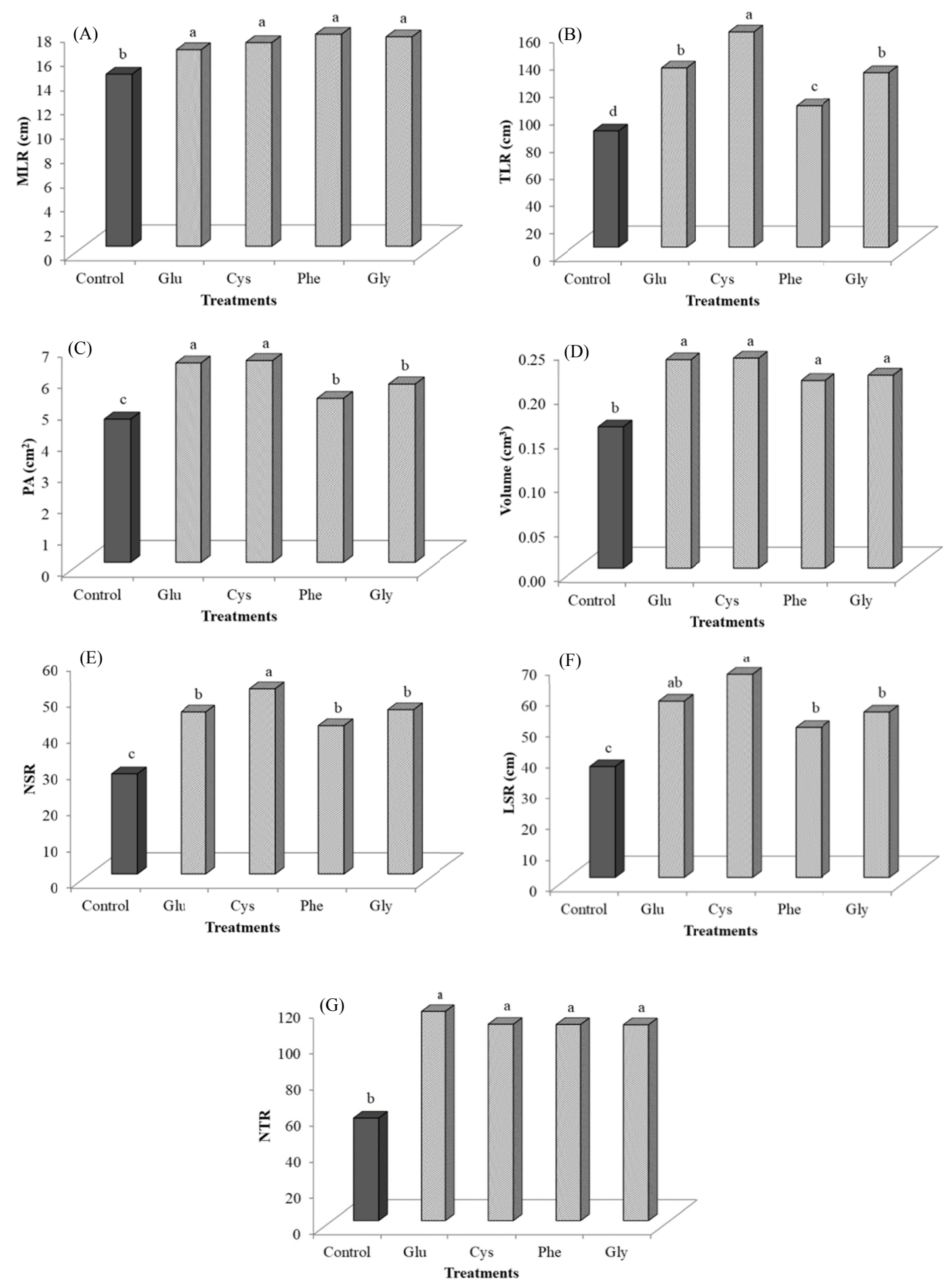

Figure 1. Effects of glutamate (Glu), cysteine (Cys), phenylalanine (Phe) and glycine (Gly) as function of seed treatment (ST) on the A: main length root (MLR, cm), B: total length of root (TLR, cm), C: project area (PA, $\left.\mathrm{cm}^{2}\right)$, D: root volume $\left(\mathrm{cm}^{3}\right)$, E: number of secondary roots (NSR), F: length of secondary root (LSR, $\left.\mathrm{cm}\right), \mathrm{G}$ : number of tertiary roots (NTR), at $\mathrm{V}_{4}$ stage. Means followed by the same letters do not differ significantly from each other, using the Duncan test at $5 \%$ significance 

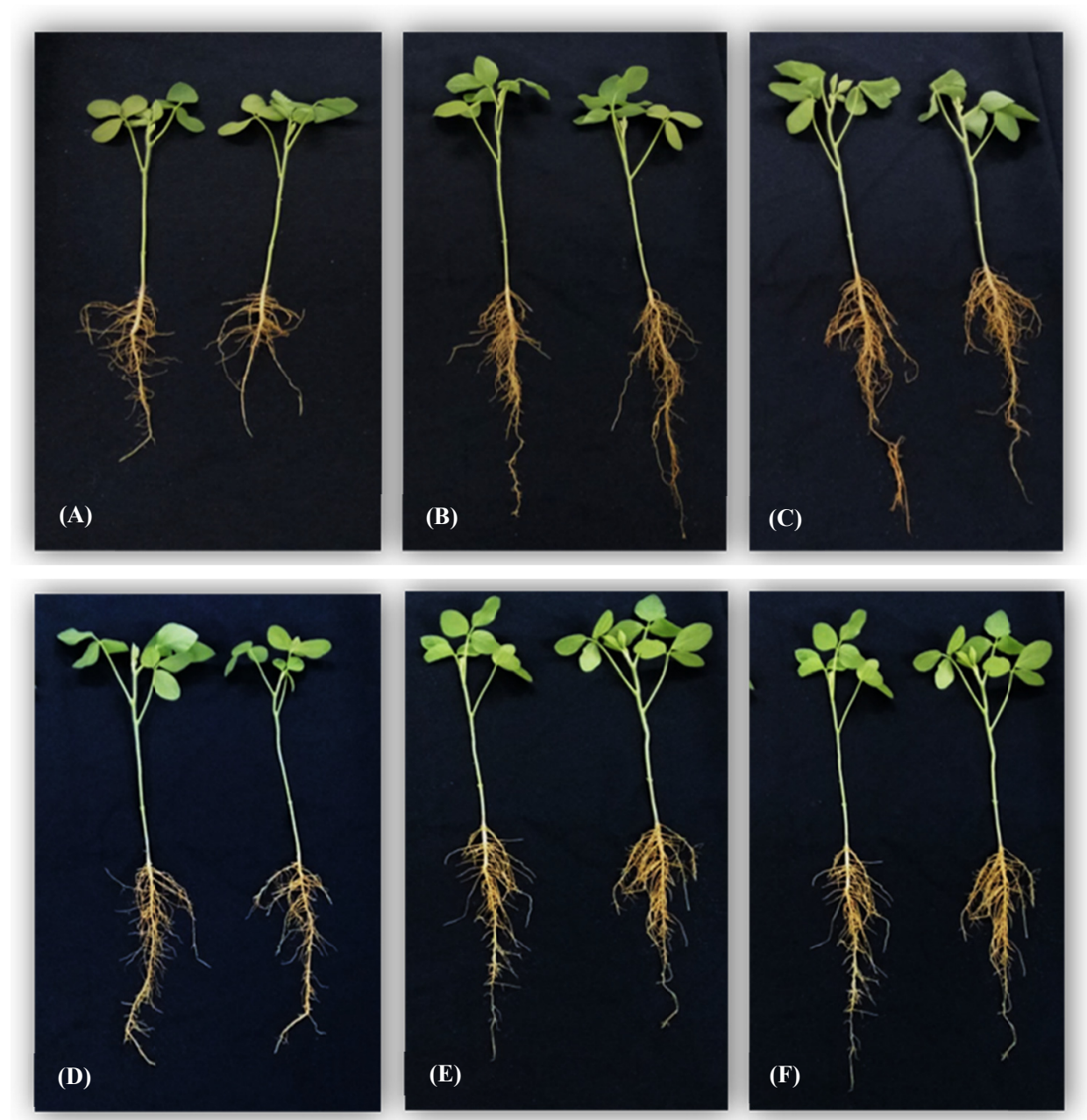

Figure 2. Effects of the amino acids as function of seed treatment (ST). Control (A), glutamate (B), cysteine (C), phenylalanine (D), glycine (E) and all these amino acids in association (F), at $\mathrm{V}_{4}$ stage

Root growth also increased in stage $\mathrm{V}_{6}$ following leaf-applied amino acids, in addition to the ongoing benefits of seed application (Figures 3 and 4). Applying cysteine on leaves raised all the root development parameters assessed (Figures 3 and $4 \mathrm{H}$ ), ranging from $27 \%$ in total root length to $69 \%$ in main root length, when compared to controls.

The use of glycine in seed and leaf treatments increased root growth (Figures $4 \mathrm{E}$ and $4 \mathrm{~J}$ ). Foliar application of this amino acid resulted in increased main root length (Figures 3A and 3B), number (Figure 3F) and length of secondary roots (Figure $3 \mathrm{~F}$ ), which corresponds to a rise of 49,36 and $38 \%$, respectively, compared to the control treatment. Applying glycine in the seed treatment increased main root length by $54 \%$ (Figure $3 \mathrm{~A}$ ), projected area by $69 \%$ (Figure 3C), root volume by $96 \%$ (Figure 3D) and the number of tertiary roots by $119 \%$ (Figure 3G), all compared to controls. Treating seeds with phenylalanine increased the projected area and root volume by 62 and $60 \%$, respectively. Seed-applied glutamate also augmented root volume by $43 \%$ in relation to controls (Figure 3D). 

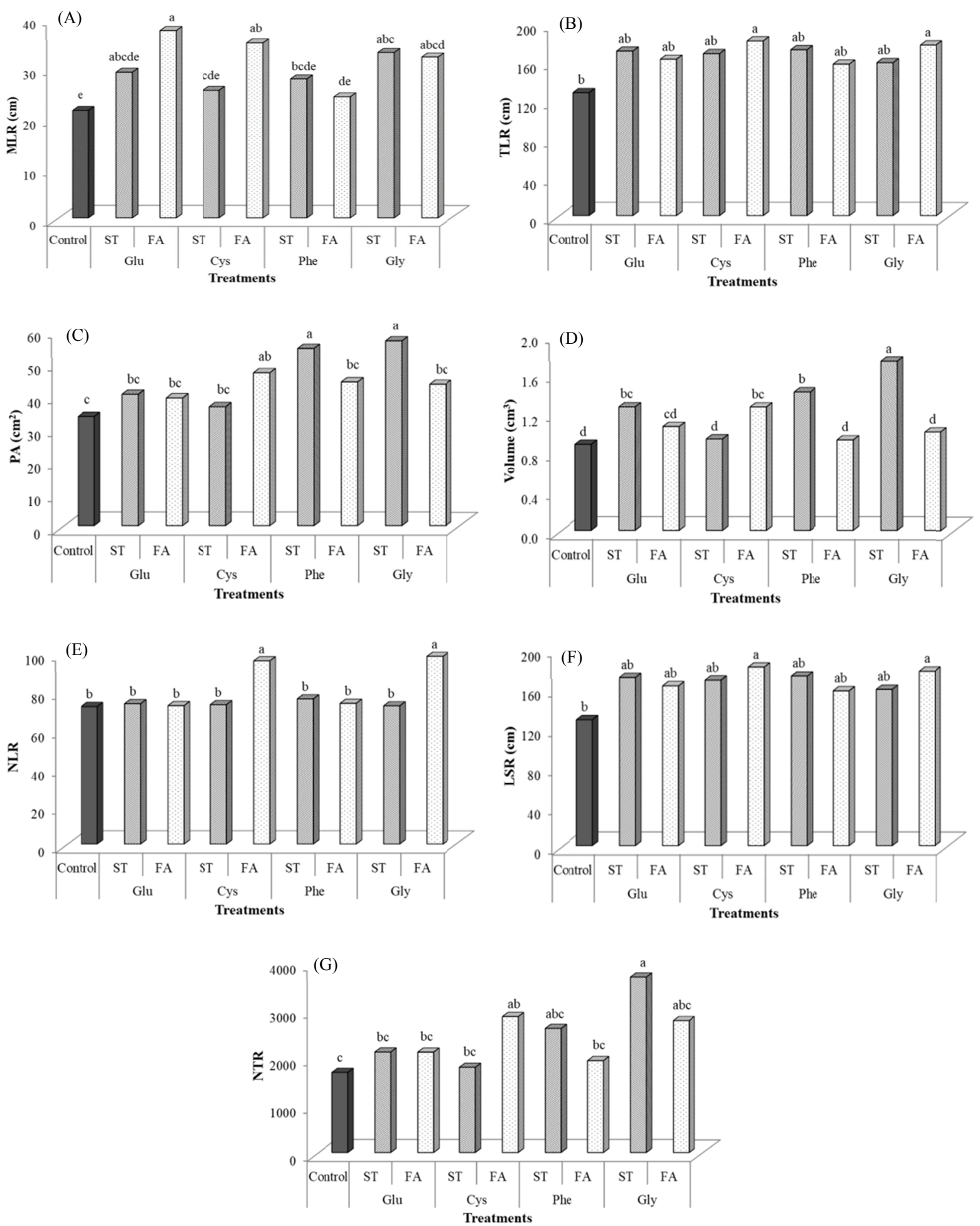

Figure 3. Effects of glutamate (Glu), cysteine (Cys), phenylalanine (Phe) and glycine (Gly) as function of seed treatment (ST) and foliar application (FA), on the A: main length root (MLR, cm), B: total length of root (TLR, $\mathrm{cm}), \mathrm{C}$ : project area $\left(\mathrm{PA}, \mathrm{cm}^{2}\right)$, D: root volume $\left(\mathrm{cm}^{3}\right), \mathrm{E}$ : number of secondary roots (NSR), F: length of secondary root (LSR, cm), G: number of tertiary roots (NTR), at $\mathrm{V}_{6}$ stage. Means followed by the same letters do not differ significantly from each other, using the Duncan test at $5 \%$ significance 

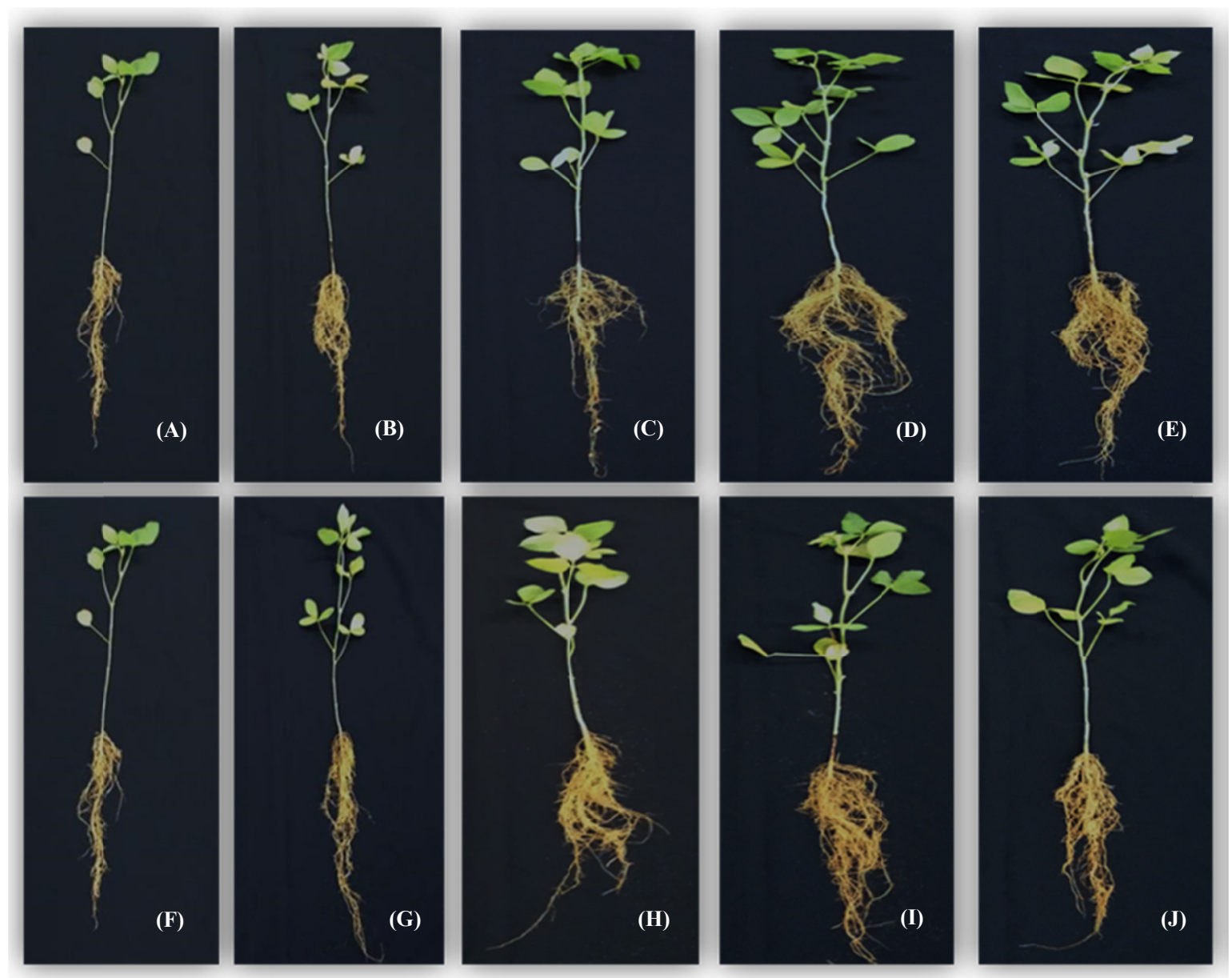

Figure 4. Effects of amino acids as function of seed treatment: Control (A), glutamate (B), cysteine (C), phenylalanine (D) and glycine (E); foliar application: control $(\mathrm{F})$, glutamate $(\mathrm{G})$, cysteine $(\mathrm{H})$, phenylalanine (I) and glycine $(\mathrm{J})$ at $\mathrm{V}_{6}$ stage

\section{Discussion}

Applying amino acids to seeds improved root growth (Figures 1 and 2). Application during this period may result in benefits, starting from the emergence of the primary root, which affects the entire morphology of the root. Cysteine was the amino acid that performed best, favoring root length, number and length of secondary root (Figures 1E and $1 \mathrm{~F}$ ). This amino acid can signal root hair growth and plant response to pathogens (Romero et al., 2014).

Cysteine is one of the first amino acids to trigger the formation of protein tertiary or quaternary structure that provide disulfide groups, which are covalent bonds used in protein formation and stability (Buchanan et al., 2000), structures that can also benefit root growth. Proteins play a number of roles in plants, including tissue formation, cellular composition, enzyme formation, and hormones, among others (Taiz et al., 2017). Leaf-applied cysteine also raised all root-related parameters (Figures 3 and $4 \mathrm{H}$ ). The use of this amino acid can indirectly induce root formation because it acts in the photosynthetic process. Since the sulfur derived from this amino acid is present in the electron transport system of photosystems, it is essential in maintaining photosynthetic metabolism (Taiz et al., 2017). Thus, the use of cysteine may have increased the rate of photosynthesis, thereby providing a larger amount of photoassimilates, which were used to produce the plant roots.

Glycine affected root development in both seed and leaf treatments. Glycine applied to the roots of Capsicum chinense at a concentration of $100 \mathrm{mM}$ inhibited main root growth and root hair formation (Domínguez-May et al., 2013). These benefits can be explained by the fact that this amino acid is part of the structure of a number of proteins, primarily those related to cell wall formation, with around $70 \%$ of these proteins formed by glycine (Buchanan et al., 2000; Ringli et al., 2001). 
Moreover, glycine is also involved in one of the production routes of glycine betaine, a compound that helps minimize possible saline or temperature stress (Sakamoto \& Murata, 2002; Ashraf \& Foolad, 2007; Taiz et al., 2017). Glycine betaine can stabilize protein and enzyme structures and protect cell membrane integrity (Sakamoto \& Murata, 2002), characteristics that can also benefit root development.

Cysteine and glycine have also been related to stress attenuation in plants (Azarakhsh et al., 2015; Teixeira et al., 2017). Glycine can help in the production of glyoxylate, an $\mathrm{H}_{2} \mathrm{O}_{2}$-reducing compound, thereby decreasing lipid peroxidation. Furthermore, glyoxylate produces NADPH and ATP, energy molecules used in a number of metabolic processes (Azarakhsh et al., 2015). These authors observed that the use of cysteine in seeds and leaves may increase the activity of antioxidant enzymes such as catalase and phenylalanine ammonia lyase and reduce lipid peroxidation.

In an experiment with soybean, the use of cysteine and glycine in seeds increased catalase activity and when applied to the leaves, these amino acids helped decrease lipid peroxidation (Teixeira et al., 2017).

Glutamate produced better results when applied in the seed treatment, with improvements in the projected area (Figure 1C) and root volume (Figure 3D). According to the literature, this amino acid is a signaler (Forde \& Roberts, 2014; Weiland et al., 2015). In roots, glutamate inhibits main root growth and increases lateral root development, which may augment root volume and area. Similar characteristics were observed in Arabidopsis after exogenous application of glutamate. In this case, at concentrations between 1 and $50 \mu \mathrm{M}$, main root growth declined when compared to controls (Walch-Liu \& Forde, 2007). This decrease is due to cell division inhibition of the apical meristem of the main root, and since the other regions of the root are not sensitive to glutamate, secondary root growth increases (Forde, 2014). The authors reported that these effects are only observed in L-glutamate (the form used here) and not in the isomer D-glutamate (Walch-Liu \& Forde, 2007). All these responses occurred because plants have glutamate receptors (GLRs) that can activate a series of physiological processes. These receptors can also be activated by other amino acids such as glycine and cysteine (Vincill et al., 2012; Forde \& Roberts, 2014).

The use of phenylalanine was also significant in seed treatment, with a rise in the projected area and volume of roots (Figures 3C and 3D). The effect of this amino acid seems to be more connected to pathways of secondary metabolism, such as flavonoid and lignin production (Taiz et al., 2017).

In addition to favoring nutrient absorption, the increased absorption area of roots caused by the amino acids seems to promote a rise in contact area in order for plant nodulation and greater nutrient absorption to occur $(\mathrm{Li}$, Zeng \& Liao, 2016). This characteristic is extremely favorable, since $50-60 \%$ of the nitrogen required by the soybean crop is obtained via biological fixation (Salvagiotti et al., 2008). Amino acids can also increase transcription of genes involved in nitrate, ammonium, phosphorous, magnesium and iron transport (Santi et al., 2017). Teixeira et al. (2018) demonstrated that applying glycine, cysteine and glutamate to seeds or leaves raises nitrate and amino acid accumulation in leaves. These characteristics are essential to plants, since they guarantee better growth and increase photosynthetic area, which leads to higher production of photoassimilates that can be used during the grain-filling phase, resulting in greater yield (Board \& Modale, 2005; Soares et al., 2016; Teixeira et al., 2018).

\section{Conclusions}

Applying amino acids to seeds or leaves changes the architecture of soybean roots, thereby influencing important parameters such as root volume, projected area and number of secondary and tertiary roots. Glutamate, glycine and phenylalanine induced better responses when applied to seeds, and cysteine when applied to leaves. All of these changes may help increase water and nutrient absorption, as well as crop yields.

\section{References}

Ashraf, M., \& Foolad, M. R. (2007). Roles of glycine betaine and proline in improving plant abiotic stress resistance. Environmental and Experimental Botany, 59, 206-216. https://doi.org/10.1016/j.envexpbot. 2005.12.006

Azarakhsh, M. R., Asrar, Z., \& Mansouri, H. (2015). Effects of seed and vegetative stage cysteine treatments on oxidative stress response molecules and enzymes in Ocimum basilicum L. under cobalt stress. Journal of Soil Science and Plant Nutrition, 15, 651-662. https://doi.org/10.4067/S0718-95162015005000044

Board, J. E., \& Modali, H. (2005). Dry matter accumulation predictors for optimal yield in soybean. Crop Science, 45, 1790-1799. https://doi.org/10.2135/cropsci2004.0602 
Bouma, T. J., Nielsen, K. L., \& Koutstaal, B. (2000). Sample preparation and scanning protocol for computerised analysis of root length and diameter. Plant and Soil, 218, 185-196. https://doi.org/10.1023/A:1014905104017

Buchanan, B. B., Gruissem, W., \& Jones, R. L. (2000). Biochemistry and molecular biology of plants. Rockville, MD: American society of Plant physiologists.

Dominguez-May, A. V., Carrillo-Pech, M., Barredo-Pool, F. A., Martinez-Estevez, M., Us-Camas, R. Y., \& Moreno-Valenzuele, O. A. (2013). A novel effect for glycine on root system growth of habanero pepper. Journal the American Society for Horticultural Science, 138, 433-442.

FAO (Food and agriculture organization of the United Nations). (2011). The state of the world's land and water resources for food and agriculture (SOLAW)_Managing systems at risk. Food and Agriculture Organization of the United Nations, Rome and Earthscan, London.

Forde, B. G., \& Roberts, M. R. (2014). Glutamate receptor-like channels in plants: a role as amino acid sensors in plant defense? F1000Prime Reports, 37, 6-37. https://doi.org/10.12703/P6-37

Forde, B. G. (2014). Glutamate signalling in roots. Journal of Experimental Botany, 65, 779-787. https://doi.org/ $10.1093 / \mathrm{jxb} / \mathrm{ert} 335$

IPNI (International Plant Nutrition Institute). (2016). Soil test levels in North America: 2015 Summary Update. International Plant Nutrition Institute, Peachtree Corners.

Johnson, C. M., Stout, P. R., Broyer, T. C., \& Carlton, A. B. (1957). Comparative chlorine requirement of different plant species. Plant and Soil, 8, 337-353. https://doi.org/10.1007/BF01666323

Li, X., Zeng, R., \& Liao, H. (2016). Improving crop nutrient efficiency through root architecture modifications. Journal of Integrative Plant Biology, 58, 193-202. https://doi.org/10.1111/jipb.12434

Lynch, J. P. (1995). Root architecture and plant productivity. Plant Physiology, 109, 7-13. https://doi.org/ 10.1104/pp.109.1.7

Mi, G., Chen, F., Wu, Q., Lai, N., Yuan, L., \& Zhang, F. (2010). Ideotype root architecture for efficient nitrogen acquisition by maize in intensive cropping systems. Science China Life Sciences, 53, 1369-1373. https://doi.org/10.1007/s11427-010-4097-y

Paula-Neto, A. (2014). Eficiência de uso de fósforo por cultivares de café e adaptação morfológica do sistema radicular sob deficiência do nutriente (Unpublished Doctoral Dissertation, Escola Superior de Agricultura "Luiz de Queiroz", Universidade de São Paulo, Brazil).

Prochnow, L. I., Cunha, J. F., Jorgetto, L. O., Cantarella, H., Lavarenti, E. L., \& Fernandes, D. M. (2018). Levantamento da fertilidade do solo do estado de São Paulo. Informações Agronômicas, 161, 1-8.

Ringli, C., Keller, B., \& Ryser, U. (2001). Glycine-rich proteins as structural components of plant cell walls. Cellular and Molecular Life Sciences, 58, 1430-1441. https://doi.org/10.1007/PL00000786

Romero, L. C., Aroca, M. A., Laureano-Marín, A. M., Moreno, I., García, I., \& Gotor, C. (2014). Cysteine and cysteine-related signaling pathways in Arabidopsis thaliana. Molecular Plant, 7, 264-276. https://doi.org/ $10.1093 / \mathrm{mp} / \mathrm{sst} 168$

Sakamoto, A., \& Murata, N. (2002). The role of glycine betaine in the protection of plants from stress: Clues from transgenic plants. Plant, Cell and Environment, 25, 163-171. https://doi.org/10.1046/j.0016-8025. 2001.00790.x

Salvagiotti, F., Cassman, K. G., Specht, J. E., Walters, D. T., Weiss, A., \& Dobermann, A. (2008). Nitrogen uptake, fixation and response to fertilizer $\mathrm{N}$ in soybeans: A review. Field Crops Research, 108, 1-13. https://doi.org/10.1016/j.fcr.2008.03.001

Santi, C., Zamboni, A., Varanini, Z., \& Pandolfini, T. (2017). Growth stimulatory effects and genome-wide transcriptional changes produced by protein hydrolysates in maize seedlings. Frontiers in Plant Science, 8 , 433. https://doi.org/10.3389/fpls.2017.00433

SAS Institute. (2011). SAS/STAT Statistical Analysis System Manual 93.

Shahzad, Z. M., \& Amtmann, A. (2017). Food for thought: How nutrients regulate root system architecture. Current Opinion in Plant Biology, 39, 80-87. https://doi.org/10.1016/j.pbi.2017.06.008 
Soares, L. H., Dourado-Neto, D., Fagan, E. B., Teixeira, W. F., Reis, M. R., \& Reichardt, K. (2016). Soybean seed treatment with micronutrients, hormones and amino acids on physiological characteristics of plants. African Journal of Agricultural Research, 11, 3314-3319. https://doi.org/10.5897/AJAR2016.11229

Taiz, L., Zeiger, E., Moller, I. M., \& Murphy, A. (2017). Fisiologia e desenvolvimento vegetal. Porto Alegre, RS: Artmed.

Teixeira, W. F. (2017). Avaliação do uso de aminoácidos na cultura de soja (Unpublished Doctoral Dissertation, Escola Superior de Agricultura “Luiz de Queiroz”, Universidade de São Paulo, Brazil).

Teixeira, W. F., Fagan, E. B., Soares, L. H., Soares, J. N., Reichardt, K., \& Dourado Neto, D. (2018). Seed and foliar application of amino acids improve variables of nitrogen metabolism and productivity in soybean crop. Frontiers in Plant Science, 9, 1. https://doi.org/10.3389/fpls.2018.00396

Teixeira, W. F., Fagan, E. B., Soares, L. H., Umburanas, R. C., Reichardt, K., \& Dourado Neto, D. (2017). Foliar and seed application of amino acids affects the antioxidante metabolism of the soybean crop. Frontiers in Plant Science, 8, 327. https://doi.org/10.3389/fpls.2017.00327

Vincill, E. D., Bieck, A. M., \& Spalding, E. P. (2012). $\mathrm{Ca}^{2+}$ conduction by an amino acid-gated ion channel related to glutamate receptors. Plant Physiology, 159, 40-46. https://doi.org/10.1104/pp.112.197509

Walch-Liu, P., \& Forde, B. G. (2007). L-Glutamate as a novel modifier of root growth and branching. What's the sensor? Plant Signaling \& Behavior, 2, 284-286.

Weiland, M., Mancuso, S., \& Baluska, F. (2015). Signalling via glutamate and GLRs in Arabidopsis thaliana. Functional Plant Biology, 43, 1-25. https://doi.org/10.1071/FP15109

\section{Copyrights}

Copyright for this article is retained by the author(s), with first publication rights granted to the journal.

This is an open-access article distributed under the terms and conditions of the Creative Commons Attribution license (http://creativecommons.org/licenses/by/4.0/). 